\title{
Conservative Loan Loss Allowance and Bank Lending*
}

\author{
Yusuke TAKASU ${ }^{1}$, Makoto NAKANO ${ }^{2}$
}

Received: July 2, 2019 Revised: July 13, 2019 Accepted: July 17, 2019

\begin{abstract}
The purpose of this study is to investigate the relation between conservative loan loss accounting practice of banks, defined as accounting behavior that increases loan loss allowances against expected credit losses, and bank lending. Furthermore, we specify the macroeconomic conditions reflecting debtors' borrowing environments and analyze how these conditions affect the relation between conservative loan loss allowances and bank lending. Although existing literature reports that accounting conservatism has a direct effect on non-financial firms' investment behavior, there is little evidence about an effect of conservatism on banks' lending behavior. By exploiting data showing the links between individual Japanese firms and their individual lenders to control both loan demand and supply, we estimate OLS regressions to test the relationships among conservative loan loss allowance, bank lending, and macroeconomic conditions using a unique dataset containing bank-firm-year observations between 2001 and 2013. We find banks that have conservative loan loss allowances tend to provide fewer loans to firms with financing needs when macroeconomic conditions are good and these conservative banks are likely to provide more loans to firms when macroeconomic conditions are bad. Our findings suggest that reflecting expected credit loss into loan loss allowances can mitigate the procyclical behavior of banks.
\end{abstract}

Keywords: Financial Accounting, Banking, Accounting Conservatism, Loan Loss Allowance, Bank Lending

JEL Classification Code: G21, G30, M41.

\section{Introduction}

We investigate the relation between conservative loan loss practice of banks, defined as accounting behavior that

* We would like to thank Toyohiko Hachiya, Fumitaka Otsubo, and the conference participants at the 39th EAA annual congress, the 2016 AAA annual meeting, and the 28th Asian-Pacific Conference on International Accounting Issues for helpful comments. All errors are the responsibility of the authors. This work was supported by JSPS KAKENHI [numbers JP15H06221, JP26380600] and Management Innovation Research Center, Hitotsubashi University.

1 First Author and Corresponding Author. Associate Professor, Faculty of International Social Science, Yokohama National University, Japan [Postal Address: College of Business Admin Research Bldg. Rm 801, 79-1 Tokiwadai, Hodogaya-ku, Yokoahama-shi, Kanagawa, 240-8501 Japan]

Email: takasu-yusuke-wk@ynu.ac.jp

2 Professor, Graduate School of Business Administration, Hitotsubashi University, Japan.

Email: makoto.nakano@r.hit-u.ac.jp

$\odot$ Copyright: Korean Distribution Science Association (KODISA)

or the terms of the Commons Attribution NonCommercial License (https://creativecommons.org/licenses/by-nc/4.0/) which permits unrestricted noncommercial use, distribution, and reproduction in any medium, provided the original work is properly cited. increases loan loss allowances against expected credit losses, and lending behavior. Moreover, we specify the macroeconomic conditions and analyze how these conditions affect the relation between conservative loan loss allowances and bank lending. Through these tests, we clarify the effect of the conservativeness of loan loss allowance on the procyclicality of bank lending.

In recent times, there has been concern that loan loss accounting, especially when based on the incurred loss model that requires objective evidence of credit impairment to recognize loan losses, enhances the positive correlation between banks' lending behavior and economic cycles. There are two reasons for this. First, banks can maximize their short-term earnings by taking more risk in good economic conditions because objective evidence of credit impairment is rarely observed under these conditions, and banks do not incur loan losses. Second, banks must recognize loan losses in bad economic conditions as they find objective evidence of credit impairment under these conditions. In particular, banks have an incentive to control the change of their leverage associated with loan loss because the banking sector is subject to capital adequacy requirements and banks may be forced to adjust their loan 
portfolios, which constitute a major part of their risk assets, to offset the leverage change.

Based on the above concern, International Accounting Standards Board (IASB, 2014) has determined to introduce the expected credit loss model that requires more timely loan loss recognition than the incurred loss model. Financial Accounting Standards Board (FASB, 2012) is also trying to introduce the expected credit loss model. The expected credit loss may play a role to resolve the above concern triggered by the incurred loss model. However, whether the expected credit loss model has an effect on bank practices is an empirical matter. Although we do not have archival data based on the expected credit loss model, it is wellknown that bank loan loss practices provide a broad latitude for managerial discretion, and that the conservativeness of loan loss allowances is different across banks (e.g., Leventis, Dimitropoulos, \& Owusu-Ansah, 2013). Therefore, following prior literatures (e.g., Jin, Kanagaretnam, \& Lobo, 2018), we exploit the cross-sectional differences in the extent of how each bank reflects expected credit loss to its loan loss allowances and analyze how these differences affect bank lending. Assuming the cross-sectional difference in the conservativeness is qualitatively similar to the change in the conservativeness by introducing the expected credit loss model, our evidence helps to understand how the introduction of the expected credit loss model affects bank lending and the real economy.

In prior literatures, Beatty and Liao (2011) analyzed the relation among loan loss allowance, capital adequacy ratio, and lending behavior. They found that a positive correlation between the capital adequacy ratio and loan growth during a recessionary period is mitigated by reflecting expected credit loss in the loan loss allowance. Therefore, they considered loan loss allowance as a moderator between the capital ratio and lending growth. Other accounting conservatism literature, however, suggests that the conservativeness of the loan loss allowance affects lending behavior directly. In this study, we focus on this direct relation between conservative loan loss allowance and lending behavior and analyze the effect of economic conditions on this relation.

Our analysis provides the following two new pieces of evidence: First, we find banks that have conservative loan loss allowances tend to provide fewer loans to firms with financing needs when macroeconomic conditions, measured by the average lending attitude of financial institutions, are good. Second, we find banks that have conservative loan loss allowances are likely to provide more loans to firms when macroeconomic conditions are bad. These findings persist even when we conduct several robustness tests.
Our research makes two contributions to prior literature. First, we directly test the linkage between a conservative loan loss allowance and lending behavior. One controversial point about the transition from the incurred loss model to the expected credit loss model in loan loss accounting is whether the expected credit loss model mitigates the procyclical nature of loan loss allowance that is seen under the incurred loss model. An accounting system that triggers banks to increase their lending during good economic conditions and decrease lending during bad economic conditions may be of concern to bank regulators who seek economic growth through a stable financial system. Although this concern about the incurred loss model is frequently expressed by bank regulators, there is little empirical evidence from an academic viewpoint. Second, we extend the prior literature by studying lending behavior in the Japanese context. By using bank-year observations, Beatty and Liao (2011) controlled several fundamentals of the loan suppliers (banks) but only the macrounemployment rate for the loan users. By exploiting data that includes the linkages between individual Japanese firms and their individual lenders, we test our hypotheses using a unique data set containing bank-firm-year observations. Therefore, we can control both the lender's and borrower's fundamentals. This linkage between individual lenders and individual borrowers is critical for understanding how loan loss allowances affect bank lending behavior and the real economy.

\section{Prior Literature and Hypotheses Development}

The most relevant study is that of Beatty and Liao (2011). In their study, they focus on the capital crunch theory that suggests capital market imperfections can restrict bank lending during recessions when the risk of violating capital adequacy requirements increases. Based on the theory, they analyzed the effect of conservative loan loss allowances on the relation between the capital adequacy ratio and bank lending. Their analysis found a strong positive correlation between the capital adequacy ratio and loan growth during recessions but conservative loan loss allowance mitigates this correlation. This evidence suggests that a conservative loan loss allowance is a moderator between the capital adequacy ratio and loan growth. For credit loss management in bank practice, it is generally expected that a loan loss allowance covers expected credit loss, and capital covers unexpected credit loss. However, when the loan loss allowance does not reflect expected credit loss sufficiently, capital must absorb the excess credit loss. Therefore, banks can avoid violating capital adequacy 
requirements by predicting expected credit loss. Beatty and Liao (2011) captured this relation.

On the other hand, other prior literature indicates that accounting conservatism in itself can affect firm behavior directly (e.g., Ball \& Shivakumar, 2005; Francis \& Martin, 2010; García Lara, García Osma, \& Penalva, 2016; Watts, 2003). Conservatism is an accounting process that seeks to recognize bad news (economic losses) as an accounting loss in a timely manner. Based on agency theory, managers may choose inefficient investment projects to increase their perks and have an incentive to delay the recognition of accounting loss generated from these projects to protect their careers. However, if accounting conservatism exists, it is difficult to delay the recognition of those losses until the next generation of executives. Thus, there is a higher possibility that managers will record this accounting loss during their tenure. Management investment decision making, therefore, becomes more rigorous, and managers will refrain from beginning investment projects with either a negative net present value (NPV) or a positive NPV with low initial profitability (e.g., Ball \& Shivakumar, 2005; Francis \& Martin, 2010).

The conservative accounting practice also strengthens the monitoring process after investment implementation. According to Pinnuck and Lillis (2007), a decline in stock prices and an increase in the cost of debt due to accounting losses prompt the board of directors, block shareholders, and regulatory authorities to intervene in management. This can lead managers to pursue abandonment options to quickly improve performance and divest unprofitable projects. Therefore, a high level of conservatism causes managers to practice early withdrawal before recognizing continuous losses from projects with low profitability or a negative NPV.

As we define conservative loan loss practice as an accounting behavior that encourages more loan loss allowances against expected credit losses, conservative loan loss allowance shares aspects of accounting conservatism. Therefore, we can apply the above logic to our context. The previously mentioned investment projects are comparable, in the banking context, with lending. Extant literature about lending by Japanese banks indicates an inefficiency of bank lending during the 1990s and early 2000s (e.g., Caballero, Hoshi, \& Kashyap, 2008; Hoshi \& Kashyap, 2004; Peek \& Rosengren, 2005; Tett, 2003). In general, it is efficient to provide a loan to a firm if the firm is in temporary financial distress and is likely to recover. However, during the 1990s and early 2000s, Japanese banks continuously provided loans to firms from whom recovery was unlikely. This lending behavior is called 'evergreening' (e.g., Hoshi \& Kashyap, 2004; Tett, 2003).
Based on the accounting conservatism literature and Japanese bank lending, it is expected that banks having more conservative loan loss allowance make more rigorous credit decisions and avoid inefficient lending with a negative NPV.

Considering macroeconomic circumstances, the relation between conservative loan loss allowances and bank lending becomes more complex. For example, there is a possibility that banks make risky loans under good macroeconomic conditions and receive higher loan interest from these loans. This is because under these conditions, objective evidence of credit impairment is rarely observed and the banks do not have to recognize a loan loss allowance. The Financial Stability Forum (FSF, 2009) corroborates this point. Thus, banks, especially nonconservative banks, may increase their lending in good macroeconomic environments.

However, this relation may be reversed under bad macroeconomic conditions. This is because banks having less conservative loan loss allowances must increase them during an economic downturn, and their financial performance will decline more severely than that of conservative banks. Moreover, these non-conservative banks might increase their loan loss allowance more than expected if the banks make risky loans during good macroeconomic conditions. In fact, Beatty and Liao (2011) found that non-conservative banks become discouraged about lending during an economic downturn. Prior studies suggest that conservative banks are more competitive under bad macroeconomic conditions.

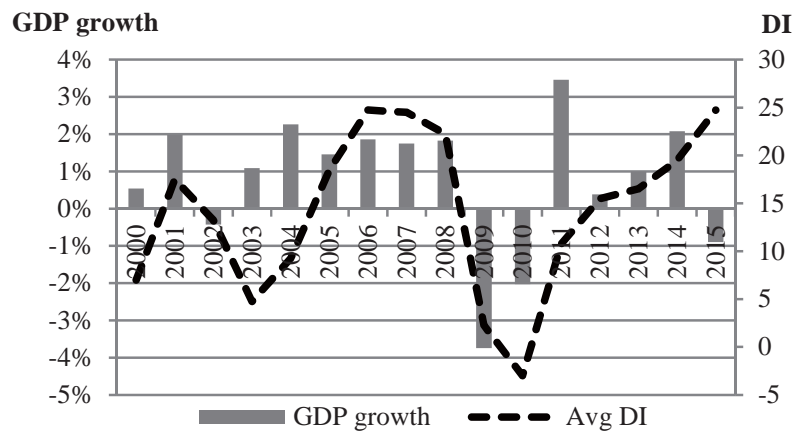

GDP growth is growth rate of real gross domestic product from fiscal year $t-1$ to $t$. The diffusion index (DI) of the lending attitude of financial institutions is provided on a quarterly basis. Therefore, we use average value of $\mathrm{DI}$ (Avg DI) in each fiscal year $t$. GDP data is collected from the Cabinet Office, Government of Japan. DI is collected from the Bank of Japan.

Figure 1: GDP growth and the diffusion index (DI) of the lending attitude of financial institutions 
As a proxy for macroeconomic conditions, we use the diffusion index (DI) of the lending attitude of financial institutions collected from the Short-Term Economic Survey of Enterprises in Japan (Tankan) conducted by the Bank of Japan to reflect the firms' borrowing conditions. According to this index, GDP growth was not fully correlated with the financing environment in Japan during the 2000s. One of the reasons the lending attitude of banks became conservative was because of the disposal of nonperforming loans due to the 'Lost Decade' during the early 2000s despite the growth of GDP (Figure 1). Therefore, we may be misled by using GDP growth as a macroeconomic condition when investigating the effect of economic expansion and downturn on the relation between conservative loan loss allowance and bank lending. From these reasons, we focus on the DI and not on GDP growth in order to investigate the effect of a conservative loan loss allowance on bank lending in different financing environments. Based on this discussion, we test the following two hypotheses:

H1: Banks that have more conservative loan loss allowances make fewer loans during good borrowing conditions than those having less conservative loan loss allowances.

H2: Banks that have more conservative loan loss allowances make more loans during bad economic conditions than those having less conservative loan loss allowances.

\section{Research Design}

\subsection{Estimation of Conservativeness of Loan Loss Allowance}

To estimate the conservativeness of loan loss allowances. we use a stock proxy variable based on Beck and Narayanamoorthy (2013), Kanagaretnam, Lim, and Lobo (2014), and Jin et al. (2018). In particular, we estimate Equation (1) and define the conservativeness of a loan loss allowance $^{2}$.

\footnotetext{
${ }^{2}$ We estimate Equation (1) by a pooling method. Based on Beaver \& Engel (1996), there is no basis for constraining the sum of discretionary behavior to be zero across all banks in a given year as a cross-sectional regression would do. This is because banks may engage in similar accounting behavior at the same time since good and bad times may be correlated within bank industry. Even when we estimate Equation (1) cross-sectionally, our primary results are unchanged.
}

$$
\begin{aligned}
L L A_{j, t}=\alpha_{0}+ & \alpha_{1} W O_{j, t}+\alpha_{2} P L_{j, t}+\alpha_{3} N P L 1_{j, t}+\alpha_{4} N P L 2_{j, t} \\
& +\alpha_{5} N P L 3_{j, t}+\alpha_{6} \text { HOM }_{j, t}+\alpha_{7} \operatorname{COM}_{j, t} \\
& +\alpha_{8} B S I Z E_{j, t}+\alpha_{9} \text { TIER } 1_{j, t}+\alpha_{10} E B T P_{j, t} \\
& +\alpha_{11} L G_{j, t}+\alpha_{12} \operatorname{SECURED}_{j, t}+\varepsilon_{j, t}
\end{aligned}
$$

where: $L L A_{j, t}=$ loan loss allowance of bank $\mathrm{j}$ at the end of fiscal year $t$ scaled by the total loans at the end of fiscal year $\mathrm{t}$; $W O_{j, t}=$ write-off of loans of bank $\mathrm{j}$ for fiscal year $\mathrm{t}$ scaled by the total loans at the end of fiscal year $\mathrm{t}-1 ; P L_{j, t}=$ claims on normal debtors of bank $\mathrm{j}$ at the end of fiscal year $\mathrm{t}$ scaled by the total loans at the end of fiscal year $\mathrm{t} ; N P L 1_{j, t}=$ claims on debtors under caution of bank $\mathrm{j}$ at the end of fiscal year $\mathrm{t}$ scaled by the total loans at the end of fiscal year $\mathrm{t}$; $N P L 2_{j, t}=$ claims on debtors under possible bankruptcy of bank $\mathrm{j}$ at the end of fiscal year $\mathrm{t}$ scaled by the total loans at the end of fiscal year $\mathrm{t} ; N P L 3_{j, t}=$ claims on debtors under virtual bankruptcy and legal bankruptcy of bank $j$ at the end of fiscal year $t$ scaled by the total loans at the end of fiscal year $\mathrm{t} ; H O M_{j, t}=$ loans to individuals of bank $\mathrm{j}$ at the end of fiscal year $t$ scaled by the total loans at the end of fiscal year $\mathrm{t}$; $\operatorname{COM}_{j, t}=$ commercial loans of bank $\mathrm{j}$ defined as total loans minus the sum of loans on individuals and on municipalities at the end of fiscal year $t$ scaled by the total loans at the end of fiscal year $\mathrm{t} ; B S I Z E_{j, t}=$ natural logarithm of the total assets of bank $\mathrm{j}$ at the end of fiscal year $t$; TIER $1_{j, t}=$ Tier1 capital divided by risk-weighted assets at the end of fiscal year $\mathrm{t} ; E B T P_{j, t}=$ earnings before taxes and loan loss provisions for fiscal year t divided by total assets at the end of fiscal year $\mathrm{t}-1 ; L G_{j, t}=$ total loans of bank $\mathrm{j}$ at the end of fiscal year $t$ scaled by the total loans at the end of fiscal year $\mathrm{t}-1$; SECURED $D_{j, t}=$ secured loans of bank $\mathrm{j}$ at the end of fiscal year $t$ scaled by the total loans at the end of fiscal year $t$.

In Equation (1), the loan loss allowance is regressed on the characteristics of loan portfolios and bank characteristics. To select control variables, we make some modifications to the model used in prior literature. In particular, we use each risk class loans variable $\left(P L_{j, t} ; N P L 1_{j, t} ; N P L 2_{j, t} ; N P L 3_{j, t}\right)$ based on the classification of nonperforming loans in the Act on Emergency Measures for the Revitalization of the Financial Functions in Japan. Furthermore, we include $S E C U R E D_{j, t}$ because loan loss allowance is used to cover the unsecured part of loans. The residuals from Equation (1) are the abnormal component of loan loss allowance, referred to as $A L L A_{j, t}$. A higher $A L L A_{j, t}$ value indicates banks recognize loan loss allowance more than expected from their loan portfolios, and we regard $A L L A_{j, t}$ as a proxy of the conservativeness of loan loss allowance.

As we define conservative loan loss practice as an accounting behavior that encourages more loan loss 
allowances against expected credit losses, conservative loan loss allowance shares aspects of accounting conservatism. Therefore, we can apply the above logic to our context. The previously mentioned investment projects are comparable, in the banking context, with lending. Extant literature about lending by Japanese banks indicates an inefficiency of bank lending during the 1990s and early 2000s (e.g., Caballero et al., 2008; Hoshi \& Kashyap, 2004; Peek \& Rosengren, 2005; Tett, 2003). In general, it is efficient to provide a loan to a firm if the firm is in temporary financial distress and is likely to recover. However, during the 1990s and early 2000s, Japanese banks continuously provided loans to firms from whom recovery was unlikely. This lending behavior is called 'evergreening' (e.g., Hoshi \& Kashyap, 2004; Tett, 2003).

\subsection{Conservative Loan Loss Allowance and Bank Lending}

To analyze the effect of conservative loan loss allowances on bank lending, we estimate Equation (2) using a unique data set containing bank-firm-year observations.

$$
\begin{aligned}
\triangle L O A N_{i, j, t+1}= & \beta_{0}+\beta_{1} \text { ALLA }_{j, t}+\beta_{2} \text { ALLA }_{j, t} * D D I_{t+1} \\
& +\beta_{3} D D I_{t+1}+\beta_{4} \text { LOANSHARE }_{i, j, t} \\
& +\beta_{5} \text { TIER }_{j, t}+\beta_{6} \Delta \operatorname{TIER}_{j, t}+\beta_{7} B S I Z E_{j, t} \\
& +\beta_{8} D E P O_{j, t}+\beta_{9} S G_{i, t}+\beta_{10} D E F_{i, t+1} \\
& +\beta_{11} \text { CASH }_{i, t}+\beta_{12} \text { ROA }_{i, t}+\beta_{13} D E_{i, t} \\
& +\beta_{14} \text { ASSET }_{i, t}+\beta_{15} P P E_{i, t}+\beta_{16} \Delta G D P_{t+1} \\
& +\Sigma \beta_{i} \text { brrower }_{i}+\epsilon_{i, j, t+1}
\end{aligned}
$$

where: $\triangle L O A N_{i, j, t+1}=$ change in long-term loans to firm i by bank $\mathrm{j}$ from the end of fiscal year $\mathrm{t}$ to the end of fiscal year $\mathrm{t}+1$ scaled by the total assets of firm $\mathrm{i}$ at the end of fiscal year $\mathrm{t} ; A L L A_{j, t}=$ abnormal loan loss allowance of bank $\mathrm{j}$ at the end of fiscal year $\mathrm{t}$ (residual from Equation (1)); $D D I_{t+1}$ $=1$ if the $\mathrm{DI}$ for fiscal year $t+1^{3}$ is in the 25th percentile within our sample window or lower, and 0 otherwise ${ }^{4}$; $\operatorname{LOANSHARE}_{i, j, t}=$ long-term loans to firm i by bank $\mathrm{j}$ at the end of fiscal year $t$ scaled by the total long-term loans of firm $\mathrm{i}$ at the end of fiscal year $\mathrm{t} ; \triangle T I E R 1_{j, t}=$ change in Tier1 capital divided by risk-weighted assets from the end of fiscal year $\mathrm{t}-1$ to the end of fiscal year $\mathrm{t} ; B S I Z E_{j, t}=$ natural

${ }^{3}$ Because the $\mathrm{DI}$ is provided on a quarterly basis, we use the average value of DI in each fiscal year.

${ }^{4}$ According to this treatment, four out of the 13 years is defined as bad borrowing conditions. However, this threshold is not objective. Therefore, as a robustness test, we use both the worst three years (a more severe threshold) and the worst five years (a milder threshold) as other thresholds to define bad borrowing conditions. The results are consistent with our primary results. logarithm of total assets of bank $\mathrm{j}$ at the end of fiscal year $\mathrm{t}$; $D E P O_{j, t}=$ deposit of bank $\mathrm{j}$ at the end of fiscal year $\mathrm{t}$ scaled by the total assets of bank $\mathrm{j}$ at the end of fiscal year $\mathrm{t} ; S G_{i, t}$ = geometric average growth rate of sales of firm i from fiscal year $\mathrm{t}-4$ to fiscal year $\mathrm{t}$; $D E F_{i, t+1}=$ funds flow deficit of firm $\mathrm{i}$ for fiscal year $t+1$ defined as the total payout by firm $i$ for fiscal year $t+1$ plus the change in working capital of firm $i$ for fiscal year $t+1$ plus capital expenditures by firm i for fiscal year $t+1$ minus the operating cash flows of firm $i$ for fiscal year $t+1$, deflated by the total assets of firm $i$ at the end of fiscal year $\mathrm{t}$; $\mathrm{CASH}_{i, t}=$ cash of firm $\mathrm{i}$ at the end of fiscal year $\mathrm{t}$ scaled by the total assets of firm $\mathrm{i}$ at the end of fiscal year $\mathrm{t}$; $R O A_{i, t}=$ earnings before extraordinary items of firm $\mathrm{i}$ for fiscal year $\mathrm{t}$ scaled by the total assets of firm $\mathrm{i}$ at the end of fiscal year $\mathrm{t}-1 ; D E_{i, t}=$ interest-bearing debt of firm $\mathrm{i}$ at the end of fiscal year $\mathrm{t}$ scaled by the total assets of firm i at the end of fiscal year $\mathrm{t} ; S I Z E_{i, t}=$ natural logarithm of the total assets of firm $\mathrm{i}$ at the end of fiscal year $\mathrm{t} ; P P E_{i, t}=$ property, plant, and equipment of firm $i$ at the end of fiscal year $t$ scaled by the total assets of firm $i$ at the end of fiscal year $t$; $\Delta G D P_{t+1}=$ real GDP growth rate for fiscal year $\mathrm{t}+1$..

In Equation (2), we exclude observations without longterm loans where we can identify the lender's name at the end of fiscal year $t$ and $t+1^{5}$. Therefore, observations in our primary analysis have long-term debt from one or more banks at the end of fiscal years $t$ and $t+1$ such that a positive $\triangle L O A N_{i, j, t+1}$ means the bank makes additional loans to the borrower. Our variables of interest are $A L L A_{j, t}$ and $A L L A_{j, t} * D D I_{t+1}$. As we use an interaction term, $A L L A_{j, t} * D D I_{t+1}$, the coefficient of $A L L A_{j, t}$ represents the effect of a conservative loan loss allowance on bank lending under good borrowing conditions. We predict the coefficient of $A L L A_{j, t}$ will be negative. The dummy variable $D D I_{t+1}$ is based on the DI. The DI is calculated by subtracting the percentage share of firms within all industries (except financial institutions) that respond the lending attitude of financial institutions is conservative from the percentage share of the firms that respond the lending attitude is

\footnotetext{
5 This is attributed to our database, Nikkei NEEDS Financial QUEST2.0. More precisely, there are three reasons. First, we can collect each loan to a borrower by a bank from this database, but loans that are not identifiable by the database vendor are recorded together as unidentifiable. Second, with regard to syndicate loans, loans from each bank are recorded separately but are bundled when there are many participant banks. Finally, some loans are recorded together as being from 'other regional banks' or 'other major banks.' For these reasons, when a certain bank name appears in the data for the first time, we cannot distinguish new loans from loans that were provided in the past but identified later. Therefore, we exclude these observations.
} 
accommodative ${ }^{6}$. The interaction term of an abnormal loan loss allowance and a lending attitude dummy $\left(A L L A_{j, t} *\right.$ $\left.D D I_{t+1}\right)$ capture an additional effect of a conservative loan loss allowance on bank lending in bad borrowing conditions. We predict this coefficient and the sum of the coefficients of $A L L A_{j, t}$ and $A L L A_{j, t} * D D I_{t+1}$ will be positive if conservative banks make more loans in bad borrowing conditions.

The lending share (LOANSHARE $E_{i, j, t}$ ) is a control variable for the relation between a bank and a firm (e.g., Ogawa, Sterken, \& Tokutsu, 2009; Petersen \& Rajan, 1994). We expect the coefficient will be positive if firms tend to borrow from their main banks. However, there is a hold-up problem stemming from the strong bargaining power of firms' main banks (e.g., Weinstein \& Yafeh, 1998), and some studies (e.g., Ogawa et al., 2009) have reported a recent weakening of these relations. Therefore, firms may borrow from other banks.

The Tier1 ratio $\left(T I E R 1_{j, t}\right)$, change in Tier1 ratio $\left(\triangle T I E R 1_{j, t}\right)$, bank total assets $\left(B S I Z E_{j, t}\right)$, and deposit $\left(D E P O_{j, t}\right)$ are control variables for the loan supply. We expect banks with a high Tier1 ratio to become aggressive in lending because of the lower risk of future capital inadequacy. Moreover, we include the change in the Tier1 ratio based on Bernanke and Lown (1991) who indicate that current changes in the capital ratio might explain future economic conditions. Considering the size effect, we also include $B S I Z E_{j, t}$ as a control variable. For example, the marginal cost of lending might be low for bigger banks because of the size effect of the cost of capital (e.g., Fama \& French, 1993). Following Ivashina and Scharfstein (2010), banks with high $D E P O_{j, t}$ might tend to provide more loans, especially in bad economic conditions, since the stability of financing sources is greater for banks depending on the deposits under the deposit insurance system.

As control variables for loan demand, we use profitability $\left(R O A_{i, t}\right)$, leverage $\left(D E_{i, t}\right)$, liquidity $\left(C A S H_{i, t}\right)$, growth potential $\left(S G_{i, t}\right)$, firm size $\left(S I Z E_{i, t}\right)$, and fixed assets $\left(P P E_{i, t}\right)$. We predict firms that are more profitable, larger, with higher growth, or more capital-intensive can utilize debt financing more actively. In contrast, we predict that highly levered or cash-rich firms tend to use less debt. Furthermore, we include cash deficit $\left(D E F_{i, t+1}\right)$ based on Shyam-Sunder and Myers (1999) and Frank and Goyal (2003). This variable is a flow-based measure that captures whether the cash outflow (e.g., change in working capital, capital expenditure, and payout) for a period is covered by the cash inflow (operating cash flow) for the same period and is higher for firms with a

\footnotetext{
6 The survey is conducted on three-point scale, such as '1) Accommodative,' '2) Not so severe,' and '3) Severe.'
}

larger cash shortage. To control other macroeconomic effects and unobserved firm fixed effects, we include the real GDP growth rate and a borrower dummy in our regression model.

Using Nikkei NEEDS Financial QUEST2.0, we can connect the outstanding amount of long-term loans to a certain firm and a certain bank at the end of every fiscal year but cannot collect deal-by-deal data. Therefore, we cannot distinguish whether our dependent variable reflects the borrower's loan needs. In short, our dependent variable will decrease when a firm does not have loan needs and repays its debt. As we are interested in whether banks change their lending behaviors depending on the conservativeness of their loan loss allowance, loan decreases due to needless loan create noise into our tests. To address this problem, we limit our sample to observations with a cash deficit $\left(D E F_{i, t+1} \geqq 0\right)^{7}$. To estimate Equation (2), we use standard errors clustered by bank and year to cope with unobserved bank and time effects (e.g., Petersen, 2009) ${ }^{8}$.

\section{Sample Selection and Descriptive Statistics}

We test our hypotheses using observations of city banks, regional banks, and non-financial debtors from the fiscal years 2001-2013 ( $t=2001-2013)$. We use non-consolidated data of banks and consolidated data of non-financial firms ${ }^{9}$. Moreover, we use financial data from 1997 to 2014 to calculate our variables. Our data was collected from Nikkei NEEDS Financial QUEST2.0 provided by Nikkei Inc., Financial Statements of All Banks provided by the Japanese Bankers Association, eol provided by Pronexus, Tankan provided by the Bank of Japan, and the System of National Accounting provided by the Cabinet Office of the Government of Japan. The data was screened according to the following criteria:

\footnotetext{
7 The reason we do not exclude observations with negative $\triangle L_{O A N}, j, t+1$ is that there is a possibility that banks do not make additional loans to firms with loan needs and collect their loans that become due. Thereby, when we exclude those observations, our sample includes only observations that can borrow loans from banks and may suffer sample selection bias.

${ }^{8}$ Even when we use standard errors clustered by year or clustered by bank-firm relation and year, our primary results remain unchanged. Further, the results are also unchanged when we include the bank-firm relation dummy variable.

${ }^{9}$ Since nonperforming loans disclosed by the Act on Emergency Measures for the Revitalization of the Financial Functions is nonconsolidated data, we use non-consolidated financial statement information of banks.
} 
Table 1: Descriptive statistics

\begin{tabular}{|c|c|c|c|c|c|c|c|c|}
\hline Variables & Mean & Std.Dev & Min & $25 \%$ & Median & $75 \%$ & Max & $\mathbf{N}$ \\
\hline$\triangle \mathrm{LOAN}$ & 0.0007 & 0.0101 & -0.0316 & -0.0026 & 0.0000 & 0.0023 & 0.0409 & 18,984 \\
\hline ALLA & 0.0007 & 0.0040 & -0.0073 & -0.0019 & 0.0001 & 0.0026 & 0.0184 & 18,984 \\
\hline LOANSHARE & 0.1530 & 0.1702 & 0.0011 & 0.0347 & 0.0954 & 0.2123 & 0.9082 & 18,984 \\
\hline TIER1 & 0.0875 & 0.0289 & 0.0440 & 0.0660 & 0.0795 & 0.1054 & 0.1631 & 18,984 \\
\hline$\triangle$ TIER1 & 0.0048 & 0.0124 & -0.0227 & -0.0010 & 0.0028 & 0.0075 & 0.0649 & 18,984 \\
\hline BSIZE & 16.6323 & 1.6265 & 13.4500 & 15.1934 & 16.1721 & 18.1431 & 18.9472 & 18,984 \\
\hline DEPO & 0.7686 & 0.1516 & 0.2598 & 0.6805 & 0.8130 & 0.8842 & 0.9377 & 18,984 \\
\hline SG & 0.0347 & 0.1001 & -0.1676 & -0.0233 & 0.0151 & 0.0692 & 0.4153 & 18,984 \\
\hline DEF & 0.0653 & 0.0679 & 0.0000 & 0.0189 & 0.0438 & 0.0863 & 0.3138 & 18,984 \\
\hline $\mathrm{CASH}$ & 0.1205 & 0.0774 & 0.0101 & 0.0639 & 0.1049 & 0.1588 & 0.3814 & 18,984 \\
\hline ROA & 0.0419 & 0.0448 & -0.0782 & 0.0159 & 0.0352 & 0.0626 & 0.1901 & 18,984 \\
\hline $\mathrm{DE}$ & 0.3305 & 0.1664 & 0.0384 & 0.2049 & 0.3123 & 0.4417 & 0.7611 & 18,984 \\
\hline SIZE & 10.9433 & 1.5788 & 8.0281 & 9.8096 & 10.7613 & 11.7860 & 15.7016 & 18,984 \\
\hline$\triangle \mathrm{GDP}$ & 0.0084 & 0.0185 & -0.0374 & 0.0039 & 0.0146 & 0.0183 & 0.0346 & 18,984 \\
\hline
\end{tabular}

Table 2: Correlation matrix

\begin{tabular}{|c|c|c|c|c|c|c|c|c|c|c|c|c|c|c|c|c|}
\hline & $(\mathrm{N}=18,984)$ & (1) & (2) & (3) & (4) & (5) & (6) & (7) & (8) & (9) & (10) & (11) & (12) & (13) & (14) & (15) \\
\hline (1) & $\triangle \mathrm{LOAN}$ & & -0.02 & -0.15 & 0.03 & -0.02 & -0.02 & 0.02 & 0.04 & 0.06 & -0.09 & 0.04 & 0.02 & 0.13 & 0.03 & -0.03 \\
\hline (2) & ALLA & -0.02 & & 0.07 & -0.04 & -0.05 & 0.20 & -0.30 & 0.01 & -0.01 & -0.01 & 0.02 & -0.03 & 0.03 & 0.00 & 0.10 \\
\hline (3) & LOANSHARE & -0.08 & 0.04 & & 0.00 & 0.05 & 0.40 & -0.33 & -0.04 & 0.06 & 0.18 & 0.05 & -0.31 & -0.41 & -0.07 & -0.04 \\
\hline (4) & TIER1 & 0.02 & -0.09 & 0.02 & & 0.40 & 0.14 & -0.06 & -0.17 & -0.02 & 0.03 & 0.01 & -0.07 & 0.10 & 0.01 & 0.01 \\
\hline (5) & $\Delta$ TIER1 & -0.02 & -0.04 & 0.05 & 0.37 & & 0.16 & -0.05 & -0.07 & 0.02 & 0.04 & 0.03 & -0.03 & 0.02 & -0.03 & 0.19 \\
\hline (6) & BSIZE & 0.02 & 0.19 & 0.27 & 0.16 & 0.20 & & -0.84 & -0.04 & 0.01 & 0.05 & 0.04 & -0.17 & -0.04 & -0.02 & -0.05 \\
\hline (7) & DEPO & 0.00 & -0.17 & -0.17 & -0.16 & -0.15 & -0.72 & & 0.03 & 0.00 & 0.01 & -0.04 & 0.13 & -0.01 & 0.00 & 0.07 \\
\hline (8) & SG & 0.06 & 0.01 & -0.03 & -0.17 & -0.07 & -0.04 & 0.04 & & 0.13 & -0.02 & 0.52 & -0.01 & 0.03 & -0.01 & -0.01 \\
\hline (9) & DEF & 0.10 & -0.01 & 0.06 & -0.04 & 0.01 & 0.01 & 0.02 & 0.22 & & 0.16 & 0.10 & 0.01 & -0.13 & -0.18 & -0.01 \\
\hline (10) & $\mathrm{CASH}$ & -0.03 & 0.01 & 0.17 & 0.04 & 0.04 & 0.05 & 0.04 & 0.07 & 0.20 & & 0.14 & -0.17 & -0.35 & -0.37 & 0.05 \\
\hline (11) & ROA & 0.07 & 0.02 & 0.02 & 0.00 & 0.00 & 0.03 & -0.02 & 0.51 & 0.14 & 0.16 & & -0.27 & 0.03 & -0.10 & 0.00 \\
\hline (12) & $\mathrm{DE}$ & 0.00 & -0.03 & -0.25 & -0.08 & -0.03 & -0.17 & 0.09 & 0.03 & 0.04 & -0.17 & -0.25 & & 0.11 & 0.21 & 0.00 \\
\hline (13) & SIZE & 0.01 & 0.00 & -0.34 & 0.09 & 0.01 & -0.06 & -0.07 & -0.02 & -0.16 & -0.36 & -0.02 & 0.16 & & 0.00 & 0.00 \\
\hline (14) & PPE & 0.03 & -0.01 & -0.09 & 0.01 & -0.02 & -0.02 & -0.01 & -0.06 & -0.19 & -0.38 & -0.11 & 0.21 & 0.00 & & -0.05 \\
\hline (15) & $\triangle \mathrm{GDP}$ & -0.04 & 0.13 & -0.02 & 0.06 & 0.26 & -0.04 & 0.06 & -0.08 & 0.00 & 0.07 & 0.00 & 0.01 & 0.01 & -0.07 & \\
\hline
\end{tabular}

Non-financial firms

1. Fiscal year-end must be in March.

2. Firms must be compliant with Japanese accounting standards.

3. A fiscal period must have 12 months.

4. Firms with cash deficit.

Banks

1. Fiscal year-end must be in March.
2. Firms must be compliant with Japanese accounting standards.

3. A fiscal period must have 12 months.

4. Banks that do not experience mergers and acquisitions for fiscal years $t$ or $t+1$.

Through the use of these criteria, a final sample of 18,984 bank-firm-year observations consisting of 123 banks and 1,767 non-financial firms were generated. Furthermore, to ensure that the results are not sensitive to outliers, we 
winsorized each continuous variable at the 1st and 99th percentiles.

Tables 1 and 2 provide the descriptive statistics and correlation matrix for the variables used in Equation (2). Higher correlations are observed between some variables. However, when we compute the variance inflation factors, all variables are less than 10 , which is the level suspected in the presence of multicollinearity. This implies that multicollinearity does not distort the estimation results.

\section{Estimation Results}

\subsection{Primary Results}

Table 3: Primary results

\begin{tabular}{|c|c|c|c|c|}
\hline $\begin{array}{c}\text { Dependent variable: } \\
\boldsymbol{\Delta L O A N}\end{array}$ & prediction & Coefficient & [std. err] & \\
\hline Cons & \pm & -0.0027 & {$[0.0073]$} & \\
\hline ALLA $\left(\beta_{1}\right)$ & - & -0.0806 & {$[0.0217]$} & $* * *$ \\
\hline ALLA $^{*} \mathrm{DDI}\left(\beta_{2}\right)$ & + & 0.1745 & {$[0.0479]$} & $* * *$ \\
\hline DDI & \pm & 0.0003 & {$[0.0006]$} & \\
\hline LOANSHARE & \pm & -0.0064 & {$[0.0012]$} & $* * *$ \\
\hline TIER1 & + & 0.0074 & {$[0.0039]$} & $* *$ \\
\hline$\Delta$ TIER1 & \pm & -0.025 & {$[0.0076]$} & $* * *$ \\
\hline BSIZE & + & 0.0003 & {$[0.0001]$} & $* * *$ \\
\hline DEPO & + & 0.0002 & {$[0.0006]$} & \\
\hline SG & + & 0.0000 & {$[0.0014]$} & \\
\hline DEF & + & 0.0233 & {$[0.0024]$} & $* * *$ \\
\hline CASH & - & -0.018 & {$[0.0057]$} & $* * *$ \\
\hline ROA & + & 0.0072 & {$[0.0067]$} & \\
\hline DE & - & -0.0096 & {$[0.0023]$} & $* * *$ \\
\hline SIZE & + & 0.0002 & {$[0.0006]$} & \\
\hline PPE & + & 0.0009 & {$[0.0028]$} & \\
\hline$\Delta$ GDP & \pm & -0.0099 & {$[0.0145]$} & \\
\hline Adj R & & & 0.1164 & \\
\hline N & & & 18,984 & \\
\hline$\beta_{1}+\beta_{2}$ & + & 0.0939 & {$[0.0343]$} & $* *$ \\
\hline Linear combination test & Prediction & & \\
\hline
\end{tabular}

Standard errors are presented in bracket. All standard errors are clustered by banks and years. ${ }^{* * *}$ and ${ }^{* *}$ indicate significance at the $1 \%$ and $5 \%$ levels, respectively (two-tailed or one-tailed, as appropriate).

Table 3 shows our primary results. The coefficient of $A L L A_{j, t}$ is negative $(-0.0806)$ and statistically significant at the $1 \%$ level. The coefficient of the interaction term, $A L L A_{j, t} * D D I_{t+1}$, is positive (0.1745) and statistically significant at the $1 \%$ level. Therefore, this result suggests the effects of conservative loan loss allowances on bank lending are reversed depending on macro borrowing conditions. Moreover, the sum of the coefficients of $A L L A_{j, t}$ and $A L L A_{j, t} * D D I_{t+1}$ and its significance level are presented at the bottom of the table. This sum of the two coefficients indicates the net effect of conservative loan loss allowances on bank lending under bad borrowing conditions. The sum of the coefficients is positive (0.0939) and statistically significant at the $1 \%$ level. In short, these results indicate that there is a negative relation between conservative loan loss allowances and bank lending under good borrowing conditions. This relation is reversed in bad borrowing conditions, and banks that have conservative loan loss allowances tend to provide more loans in those periods. Therefore, the results support our two hypotheses.

Regarding our control variables, the coefficient of the lending share, which captures bank-firm relations, is negative and statistically significant. This means firms with strong ties to certain banks tend not to borrow from those banks. This result is consistent with prior literature (e.g., Ogawa et al., 2009, indicating bank-firm relations have weakened. The positive coefficient of $T I E R 1_{j, t}$ is consistent with our prediction that banks with stronger capital tend to lend more. The coefficient of changes in the Tier1 ratio is negative, similar to Bernanke and Lown (1991) and Beatty and Liao (2011). This may reflect a bank decreasing its lending to decrease risk assets and achieve a higher Tier1 ratio. The coefficients of the bank total assets $\left(B S I Z E_{j, t}\right)$ and deposit to total assets ratio $\left(D E P O_{j, t}\right)$ are both positive and consistent with our predictions.

For the borrower control variables, the cash deficit $\left(D E F_{i, t}\right)$, cash holding $\left(C A S H_{i, t}\right)$, and debt ratio $\left(D E_{i, t}\right)$ affect bank lending significantly. These results indicate that firms with a cash deficit or smaller cash holdings tend to demand bank loans. Further, banks seem to be careful lending to firms that have more debt.

It seems inconsistent that there is a negative relation between real GDP growth $\left(\Delta G D P_{t+1}\right)$ and bank lending. This result may be because financing needs are satisfied by internal funds or direct capital markets, such as bond markets and equity markets, during economic expansion, and the demand for bank loans increases with the shortage of internal funds and the illiquidity of direct capital markets experienced during an economic downturn ${ }^{10}$.

Our primary results presented in Table 3 show that the effect of a conservative loan loss allowance on bank lending is negative in good borrowing conditions and positive in bad borrowing conditions. These results are consistent with $\mathrm{H} 1$ and $\mathrm{H} 2$ and indicate that a conservative loan loss allowance lowers the positive synchronicity between bank lending and macroeconomic conditions.

\footnotetext{
${ }^{10}$ It is reported that the demand for bank loans increased in the financial crisis of the late of 2000 s, such as 'recordable growth of bank lending in major 6 banks for the first time in 17 years' (The Nikkei 12/6/2008, in Japanese) and 'financing shifts to bank loans' (The Nikkei 12/10/2008, in Japanese).
} 


\subsection{Robustness Tests}

Our primary analysis supports our hypotheses. In this section, we test the robustness of our primary results. In particular, we analyze the effect of conservative loan loss allowances on bank lending using a sample containing not only cash deficit observations but also non-cash deficit observations to investigate another specification of firms' loan demands. In particular, we define a new dummy variable, $D D E F_{i, t+1}$, which is 1 if $D E F_{i, t+1}$ is zero or higher and 0 otherwise and focus on the interaction terms, $D D E F_{i, t+1} * A L L A_{j, t}$ and $D D E F_{i, t+1} * A L L A_{j, t} * D D I_{t+1}$, to analyze the effect of conservative loan loss allowances on bank lending to firms with or without cash deficit.

Table 4: Estimation results including non-cash deficit observations

\begin{tabular}{|c|c|c|c|c|}
\hline $\begin{array}{c}\text { Dependent variable: } \\
\Delta \text { LOAN }\end{array}$ & Prediction & Coefficient & [std. err] & \\
\hline Cons & \pm & -0.0008 & {$[0.0048]$} & \\
\hline $\operatorname{ALLA}\left(\gamma_{1}\right)$ & \pm & -0.0261 & {$[0.0197]$} & \\
\hline DDEF*ALLA $\left(\gamma_{2}\right)$ & - & -0.0387 & {$[0.0170]$} & ** \\
\hline ALLA *DDI $\left(\gamma_{3}\right)$ & \pm & 0.0362 & {$[0.0481]$} & \\
\hline DDEF $^{*}$ ALLA*DDI $\left(\gamma_{4}\right)$ & + & 0.0939 & {$[0.0285]$} & *** \\
\hline DDEF*DDI & \pm & 0.0000 & {$[0.0003]$} & \\
\hline DDEF & + & 0.0001 & \begin{tabular}{|l|}
{$[0.0002]$} \\
\end{tabular} & \\
\hline DDI & \pm & 0.0005 & {$[0.0005]$} & \\
\hline Other control variables & & \multicolumn{2}{|c|}{ Yes } & \\
\hline Adj $R^{2}$ & & & 0.0934 & \\
\hline $\mathrm{N}$ & & & 42,493 & \\
\hline Linear combination test & Prediction & & & \\
\hline$\gamma_{1}+\gamma_{2}$ & - & -0.0648 & {$[0.0275]$} & $* * *$ \\
\hline$\gamma_{1}+\gamma_{2}+\gamma_{3}+\gamma_{4}$ & + & 0.0654 & {$[0.0319]$} & ** \\
\hline
\end{tabular}

Control variables in Equation 2 are included in the estimation but abbreviated in the tables. Standard errors are presented in bracket. All standard errors are clustered by banks and years. ${ }^{* * *}$ and ** indicate significance at the $1 \%$ and $5 \%$ levels, respectively (twotailed or one-tailed, as appropriate).

Table 4 presents the estimation results using the alternative specification. Regarding the observations with cash deficits, banks that have conservative loan loss allowances tend to provide fewer loans under good borrowing conditions (the sum of the coefficients of $A L L A_{j, t}$ and $\left.D D E F_{i, t+1} * A L L A_{j, t}\right)$ and more loans under bad borrowing conditions (the sum of the coefficients of $A L L A_{j, t}$, $D D E F_{i, t+1} * A L L A_{j, t}, A L L A_{j, t} * D D I_{t+1}$, and $D D E F_{i, t+1} *$ $\left.A L L A_{j, t} * D D I_{t+1}\right)$. Moreover, for observations with non-cash deficits, the coefficient of the abnormal loan loss allowance and that of the interaction terms with $D D I_{t+1}$ are negative and positive, respectively, but insignificant. These results suggest that including observations with non-cash deficits creates noise in our analysis.

In addition to the above robustness tests, as we have noted in the endnotes, we also conducted robustness tests for (1) definitions for macroeconomic conditions, (2) crosssectional estimates of abnormal loan loss allowance, and (3) a bank-firm relation dummy in Equation 2. These results are qualitatively similar to our primary results and enhance the validity of our conclusion.

\section{Conclusion}

We investigated the relation between conservative loan loss allowances and bank lending by using a unique Japanese data set. When banks timely reflect expected credit loss to their loan loss allowance, provision of loans may generate credit loss even when economic conditions are good. Therefore, banks that have conservative loan loss allowances tend to be careful when making loans. However, banks that have less conservative loan loss allowances are required to recognize more credit loss when economic conditions become worse. Under poor economic conditions, it is expected that conservative banks have a competitive advantage over other banks. Our primary analysis supports this conjecture, and the results are confirmed even when applying several robustness tests.

Our findings suggest that integrating expected credit loss into loan loss allowances enhances the conservativeness of the loan loss allowance and can mitigate the procyclical behavior of banks. Although our findings are similar to those of Beatty and Liao (2011), we extend their research using a unique Japanese dataset and find new evidence that conservative loan loss allowances may decrease bank lending under good economic conditions.

\section{References}

Ball, R., \& Shivakumar, L. (2005). Earnings quality in UK private firms: Comparative loss recognition timeliness. Journal of Accounting and Economics, 39(1), 83-128.

Beatty, A., \& Liao, S. (2011). Do delays in expected loss recognition affect banks' willingness to lend? Journal of Accounting and Economics, 52(1), 1-20.

Beaver, W. H., \& Engel, E. E. (1996). Discretionary behavior with respect to allowances for loan losses and the behavior of security prices. Journal of Accounting and Economics, 22(1-3), 177-206.

Beck, P. J., \& Narayanamoorthy, G. S. (2013). Did the SEC impact banks' loan loss reserve policies and their 
informativeness? Journal of Accounting and Economics, 56(2-3, Supplement 1), 42-65.

Bernanke, B., \& Lown, C. S. (1991). The credit crunch. Brookings Papers on Economic Activity, 22(2), 205-248.

Caballero, R. J., Hoshi, T., \& Kashyap, A. K. (2008). Zombie lending and depressed restructuring in Japan. American Economic Review, 98(5), 1943-1977.

Fama, E. F., \& French, K. R. (1993). Common risk factors in the returns on stocks and bonds. Journal of Financial Economics, 33(1), 3-56.

Financial Accounting Standards Board. (2012). Proposed accounting standards update: Financial instrumentscredit losses (subtopic 825-15). Norwalk, CT: Financial Accounting Standards Board.

Financial Stability Forum. (2009). Report of the FSF working group on provisioning: Financial Stability Forum.

Francis, J. R., \& Martin, X. (2010). Acquisition profitability and timely loss recognition. Journal of Accounting and Economics, 49(1-2), 161-178.

Frank, M. Z., \& Goyal, V. K. (2003). Testing the pecking order theory of capital structure. Journal of Financial Economics, 67(2), 217-248.

García Lara, J. M., García Osma, B., \& Penalva, F. (2016). Accounting conservatism and firm investment efficiency. Journal of Accounting and Economics, 61(1), 221-238.

Hoshi, T., \& Kashyap, A. K. (2004). Japan's financial crisis and economic stagnation. Journal of Economic Perspectives, 18(1), 3-26.

International Accounting Standards Board. (2014). IFRS9 financial instruments. London, England: International Accounting Standards Board.

Ivashina, V., \& Scharfstein, D. (2010). Bank lending during the financial crisis of 2008. Journal of Financial Economics, 97(3), 319-338.

Jin, J., Kanagaretnam, K., \& Lobo, G. J., (2018). Discretion in bank loan loss allowance, risk taking and earnings management. Accounting \& Finance, 58(1), 171-193.

Kanagaretnam, K., Lim, C. Y., \& Lobo, G. J. (2014). Influence of national culture on accounting conservatism and risk-taking in the banking industry. Accounting Review, 89(3), 1115-1149.

Leventis, S., Dimitropoulos, P., \& Owusu-Ansah, S. (2013). Corporate governance and accounting conservatism: Evidence from the banking industry. Corporate Governance: An International Review, 21(3), 264-286.

Ogawa, K., Sterken, E., \& Tokutsu, I. (2009). Multiple bank relationships and the main bank system: Evidence from a matched sample of Japanese small firms and main banks. In G. Calcagnini \& E. Saltari (Eds.), The economics of imperfect markets: The effects of market imperfections on economic decision-making (pp.73-90). Heidelberg, Germany: Physica-Verlag HD.

Peek, J., \& Rosengren, E. S. (2005). Unnatural selection: Perverse incentives and the misallocation of credit in Japan. American Economic Review, 95(4), 1144-1166.

Petersen, M. A. (2009). Estimating standard errors in finance panel data sets: Comparing approaches. Review of Financial Studies, 22(1), 435-480.

Petersen, M. A., \& Rajan, R. G. (1994). The benefits of lending relationships: Evidence from small business data. Journal of Finance, 49(1), 3-37.

Pinnuck, M., \& Lillis, A. M. (2007). Profits versus losses: Does reporting an accounting loss act as a heuristic trigger to exercise the abandonment option and divest employees? Accounting Review, 82(4), 1031-1053.

Shyam-Sunder, L., \& Myers, S. C. (1999). Testing static tradeoff against pecking order models of capital structure. Journal of Financial Economics, 51(2), 219-244.

Tett, G. (2003). Saving the sun: A wall street gamble to rescue japan from its trillion-dollar meltdown. New York, NY: Harper Business.

Watts, R. L. (2003). Conservatism in accounting part I: Explanations and implications. Accounting Horizons, 17(3), 207-221.

Weinstein, D. E., \& Yafeh, Y. (1998). On the costs of a bank-centered financial system: Evidence from the changing main bank relations in Japan. Journal of Finance, 53(2), 635-672. 